\title{
1,4-ジメチル-1,4-ビス(メチル置換フェニル)- 2-テトラゼンの熱分解
}

(1978 年 11 月 13 日受理)

\author{
小田 哲雄* ・ 前 嶋 俊 壽* ・杉山一男**
}

2-テトラゼンの分解に括よぼす立体的な因子を明らかにするために， 7 種の 1,4-ジメチル-1,4-ビス (メチル直換フェニル)-2-テトラゼン[1]を合成した。[1]はスペクトルデータから2 種の立体配座を とることがわかった。すなわちフェニル基の 3 あるいは 4 位にメチル基をるつ[1 a, b, c, d] は transplanar 型で, フェニル謤の 2 あるいは 6 位にメチル基をるつ〔1 e, f, g] は trans-orthogonal 型であ る。これら一連の [ 1$]$ を種々のプロトン性溶媒中で熱分解させた。分解速度定数 $\left(k_{\mathrm{d}}\right)$ は溶媒の極性と ともに增大した。 $k_{\mathrm{d}}$ の大きさ $[1 \mathrm{e}] \gg[1 \mathrm{~d}]>[1 \mathrm{~b}]>[1 \mathrm{c}]>[1 \mathrm{a}] \gg[1 \mathrm{~g}]>[1 \mathrm{f}]$ の順に減少 し， $\Delta H^{*}$ と溶媒の極性パラメーター $E_{\mathrm{T}}$ 值とは直線関俰を示した。また，種々の溶媒中における[1] の分解の $\Delta H^{*}$ と $\Delta S^{*}$ は，たがいに補償関係にあったことから，溶媒の種類に関係なく，〔1〕のお のおのは単一の機構で分解することがかかった。他方，〔1]の分解様式は trans-planar 体と cisorthogonal 体で異なることが示された。すなわち，〔1]は trans-planar $\stackrel{a}{\rightarrow}$ trans-orthogonal $\stackrel{b}{\longrightarrow}$ cis-orthogonal の配座変化を経て分解する。ここK，a ⿰扌よび b はそれぞれ $[1 \mathrm{a}, \mathrm{b}, \mathrm{c}, \mathrm{d}]$ 扰よび $[1 \mathrm{e}$, $\mathrm{f}, \mathrm{g}$ ]の分解に就ける律速段階である。

\section{1 楮 贯}

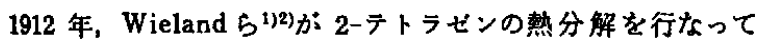
以来，種々の脂肪族扰よび芳香族 2-テトラゼン誘道体が合成さ れ，その分解に打ける熱力学的，䉓子的な因子について，多くの

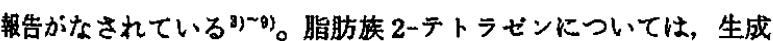

* 近教大学理工学部応用化学科，577 東大阪市小若江

** 近畿大学工学部工業化学科, 737-01 呉市仏町

1) H. Wieland, H. Fressel, Ann., 392, 133(1912).

2) H.Wieland, A.Süßer, ibid., 392, 169(1912).

3) B.G. Gowenlock, P.P. Jones, D. R. Snelling, Can. J Chem., 41, 1911(1963).

4) S.F.Nelsen, D.H.Heath, J. Am.Chem.Soc., 91, 6452 (1969).

5) R.F.Bridger, J.Org.Chem., 35, 1746(1970).

6) S.F.Nelsen, R.Fibiger, J.Am.Chem.Soc., 94, 8497 (1972).

7) S.F.Nelsen, R.T.Landis, L.H.Kiehle, T.H.Leung, ibid., 94, 1610(1972).

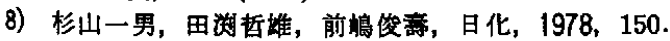

9) K.Sugiyama, T.Nakaya, M.Imoto, Makromol.Chem., 176. 2263(1975).

10) B. R. Cowley, W.A.Waters, J.Chem.Soc., 1961, 1228.

11) A.Good, J.C. J.Thynne, ibid., B, 1967, 684.

12) K.Sugiyama, T.Nakaya, M.Imoto, J.Polym.Sci, Part $A-1,10,205$ (1972).

13) K.Sugiyamn, T.Nakaya, M.Imoto, Makromol.Chem., 166, 311 (1973).

14) K. Sugiyama, T.Nakaya, M. Imoto, ibid., 175, 1497 (1974).
するアミニルラジカルのオレフィンへの付加反応性 ${ }^{10)}$ 15)や基筫

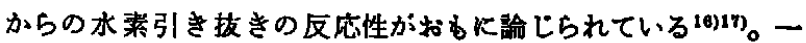
方，反応性に之しい空菜中心ラジカルを生成する 若香笑 2-テト ラゼンについては，ラジカルの安定性に関与する因子ゃ 2-テト ラゼンの構造および分解機構に興味がもたれている4 (7)18) 20)。 すでに著者らは芳香族 2-テトラゼンの分解反纫は，兹奏的でな く二段機棈で生起することを反応におよぼす溶媒の粘性 ${ }^{21) 22) ~ あ ~}$

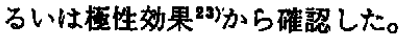

また， $\mathrm{N}^{1}, \mathrm{~N}^{4}$ に電子供与性基方殒入されると分解速度は促進 されるが(4)，このとき，エンタルピー項よりエントロピー項が 重要である。これは生成した窒素ラジカルの不対㫣子が芳香摆上

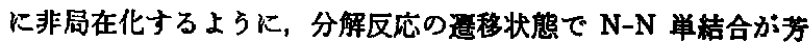

15) C. J.Michejda, D.H.Campbell, Tetrahedron Lett., 1977, 577.

16) D.Mackay, W.A.Waters, J.Chem. Soc., Org., 1966, 813.

17) C. J.Michejda, W.P.Hoss, J.Am.Chem.Soc., 92, 6298 (1970).

18) K. Sugiyama, T.Nakaya, M. Imoto, Makromol. Chem., 176, 587(1975).

19) K.Sugiyama, T.Nakaya, M.Imoto, ibid., 176, 3211 (1975).

20) K. Sugiyama, T. Tabuchi, ibid., 179, 259(1978).

21) K.Sugiyama, T.Nakaya, M. Imoto, Bull.Chem.Soc. Jpn., 48, 941(1975).

22) T.Oda, T.Maeshima, K.Sugiyama, Makromol.Chem., 179, 2331(1978).

23）杉山一男, 田㴊哲雄, 前嶋俊毫, 日化, 1977, 1158. 
Table 1 First-order rate constants $\left(k_{\mathrm{d}}\right)$ in various solvents

\begin{tabular}{|c|c|c|c|c|c|c|}
\hline \multirow{2}{*}[1]{} & \multirow{2}{*}{$\begin{array}{l}\text { Temp. } \\
\left({ }^{\circ} \mathrm{C}\right)\end{array}$} & \multicolumn{5}{|c|}{$k_{d} \times 10^{5}\left(\sec ^{-1}\right)$} \\
\hline & & Methanol & $\begin{array}{c}\text { Ethanol: Water } \\
(80: 20)\end{array}$ & Ethanol & 2-Propanol & Acetonitrile \\
\hline \multirow{5}{*}[1\mathrm{a}]{$^{a)}$} & 75 & 2.60 & - & 1.23 & 0.81 & 0.32 \\
\hline & 80 & 4.87 & - & 1.96 & 1.23 & 0.40 \\
\hline & 85 & 7.88 & - & 3. 64 & 2.23 & $0.86^{\circ}$ \\
\hline & 90 & 14.5 & 一 & 6.62 & 3. 99 & 1.37 \\
\hline & 95 & 24.8 & - & 11.1 & 4.35 & 2.68 \\
\hline \multirow{5}{*}[1\mathrm{b}]{$^{a)}$} & 75 & 14.6 & - & 5.55 & 3.70 & - \\
\hline & 80 & 23.6 & - & 9.11 & 4.25 & 1.42 \\
\hline & 85 & 47.2 & - & 13.9 & 8.74 & 2.71 \\
\hline & 90 & 72.7 & - & 27.4 & 14.4 & 4.56 \\
\hline & 95 & 111 & - & 60.0 & 24.0 & 9.07 \\
\hline \multirow{5}{*}[1\mathrm{c}]{} & 75 & 4.08 & 2.82 & 2.00 & 1.08 & 0.33 \\
\hline & 80 & 6.77 & 5.13 & 3. 39 & 2.00 & 0.64 \\
\hline & 85 & 11.3 & 9.13 & 5.89 & 3.72 & 1.23 \\
\hline & 90 & 18.7 & 15.9 & 9.78 & 6.61 & 2.54 \\
\hline & 95 & 32.4 & 27.6 & 16.3 & 12.1 & 4.27 \\
\hline \multirow{5}{*}[1\mathrm{d}]{} & 75 & 一 & - & - & - & 0.99 \\
\hline & 80 & - & - & - & - & 1.93 \\
\hline & 85 & - & - & - & - & 3.57 \\
\hline & 90 & - & - & - & - & 6.31 \\
\hline & 95 & - & - & - & - & 11.8 \\
\hline \multirow{5}{*}[1\mathrm{e}]{$^{a}$} & 55 & 9.17 & - & 2.36 & 1.78 & 0.92 \\
\hline & 60 & 16.2 & - & 4.79 & 3.42 & 1.72 \\
\hline & 65 & 27.7 & - & 7.36 & 5.75 & 2.63 \\
\hline & 70 & - & - & 15.7 & 12.7 & 6.11 \\
\hline & 175 & - & - & 25.4 & 19.6 & 9.93 \\
\hline \multirow{5}{*}[1\mathrm{f}]{} & $(100$ & - & - & - & - & - \\
\hline & 105 & 2.70 & 2.11 & 1.29 & 1.00 & 0.78 \\
\hline & $\{110$ & 4.58 & 3.61 & 2.24 & 1.78 & 1.06 \\
\hline & 115 & 7.82 & 6.20 & 4.03 & 3.00 & 1.45 \\
\hline & 120 & 12.5 & 10.0 & 6.53 & 5.03 & 3.33 \\
\hline \multirow{5}{*}[1\mathrm{g}]{} & $(100$ & 5.13 & 3.79 & 2.09 & 1.24 & 1.03 \\
\hline & 105 & 7.95 & 5. 99 & 3. 39 & 2.14 & 1.82 \\
\hline & $\{110$ & 12.6 & 9.06 & 5.63 & 3.72 & 2.28 \\
\hline & 115 & 19.5 & 14.1 & 9.13 & 6.31 & 4.09 \\
\hline & 120 & 28.9 & 20.9 & 14.2 & 10.5 & 6.71 \\
\hline
\end{tabular}

a) Ref. 23).

香等に垂直な構造をとることによることあ明らかとなった。しか し，2-テトラせンの $\mathrm{N}^{1}, \mathrm{~N}^{4}$ がフケ基 $\mathrm{N}^{2}=\mathrm{N}^{3}$ に対し，いかなる 配座を程由して分解するかは不明である。ところで，1,4-ビス (メトキシカルボニル)-1,4-ジフェニル-2-テトラセン24や 1,4シ(2-ピリジル)-2-テトラゼン23)の熱分解においては溶禁の極性 奻果が認められ，溶媒効果を受ける中心恃ルボニル基やピりジ ン摆の空秦原子であった。

しかし特别な梅性基をるたない2-テトラゼンについては，骨

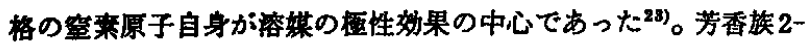
テトラぜンの分解の配座変化を明らかにするためには特別な極性 基をあたない2-テトラぜンを選ぶことが必要である。本報では， 柾性の中心が $N^{1}, N^{4}$ に期待される，数程の 1,4 -ジィチルー1,4-ビ ス(メチル居換フェニル)-2-テトラせン〔1〕を合成し，熱分解

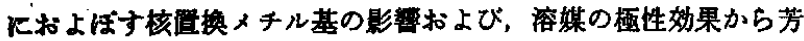
香族 2-テトラゼンは trans-planar $\longrightarrow$ trans-orthogonal $\longrightarrow$

24) K.Sugiyama, T.Nakaya, M.Imoto, Makromol. Chem., 163, 185(1973).

25）杉山一男, The ACS/CSJ Chemical Congress(Hawaii), Abstr. No. 416.

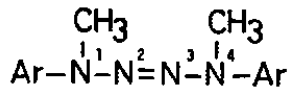

[1]

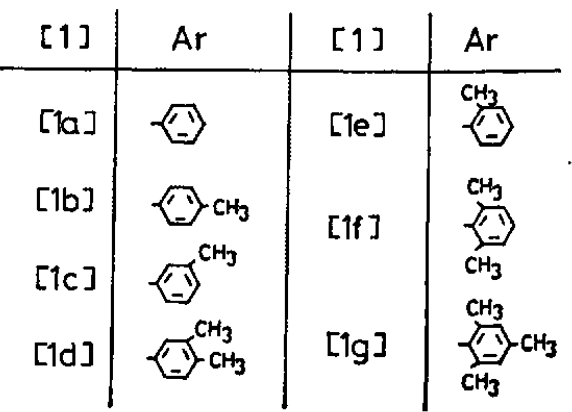

cis-orthogonal の静造変化を経て分解することを見いだした。

\section{2 結果と考察}

\section{1 プロトン性溶媒中における[1]の熱分解}

[1]の熱分解を極性の異なる 5 種の溶媒中， $55 \sim 120^{\circ} \mathrm{C}$ の温度 筑团で行なった。溶媒は $\mathrm{N}^{1}, \mathrm{~N}^{\star}$ 位の窒素へのプロトン付加の程 
Table 2 Thermodynamic parameters ${ }^{a) b)}$ in various solvent at $85^{\circ} \mathrm{C}$

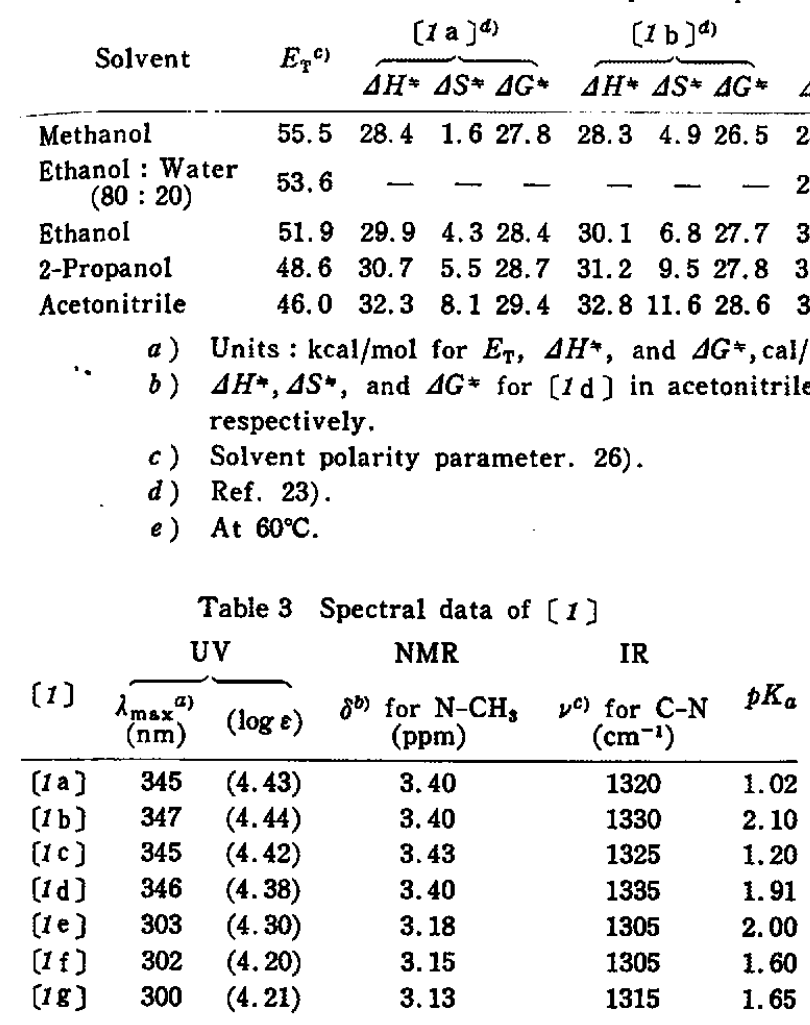

a) In acetonitrile. b) In $\mathrm{CDCl}_{3}$ (TMS).

c) In $\mathrm{CCl}_{4}$.

“度を明らかにするためブロトン性のハタノール、ェタノール、ェ タール：水 $(80: 20) ， 2$-プロパノールおよびフセトニトリルを

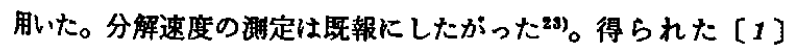
の各種溶媒中における $k_{\mathrm{d}}$ を表 1 にまとめた。 $k_{\mathrm{d}}$ の再現性はよく 明らかに溶媒のブロトン付与能26)の增加ととるに $k_{\mathrm{d}}$ は增大して いる。[1 e,f,g] はメチル基のオルト奻果27)28)が認められる。表

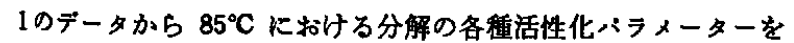
算出した。結果を表 2 にまとめる。

\section{2 〔1]の立体構造}

〔1〕のスベクトルデータの一部拈よび $p K_{a}$ を表 3 に抄録す $3_{0}$ 最長波長梗大吸収は $[1 \mathrm{a}, \mathrm{b}, \mathrm{c}, \mathrm{d}]$ の場合 $346 \mathrm{~nm}$ 付近にあ るのに対し，[1 e,f,g]の場合は $45 \mathrm{~nm}$ ほど短波長測にある。 これは, 前者がフソ基と $\mathrm{N}^{1}, \mathrm{~N}^{4}$ 位の二つのフェニル環とが同一平 面にあり窒素の非共有電子対がフェニル基の $\pi$-電子と共役して いるのに対して，後者は共役関係にないことを意味している。ま た, NMR において $[1 \mathrm{e}, \mathrm{f}, \mathrm{g}]$ の $N-$ メチプロトンが $[1 \mathrm{a}, \mathrm{b}$, c,d の $N$-メチルブロトンより高酳場にあること，および $[1 \mathrm{e}$, $f, g]$ の IR の C-N 伸縮振動か～[ $1 \mathrm{a}, \mathrm{b}, \mathrm{c}, \mathrm{d}]$ 上り低波数に出現す ること〔1〕の立体權造の相違を示している。一方，2-テトラ ゼンは基底状態で，トランス形であることが報告されている ${ }^{28)}$ 以上のことから，基底状態で [1 a, b, c, d] は trans-planar 样 造〔2]であり，[1 e,f,g] は trans-orthogonal 楼造 [3]で あると思われる。

26) K. Dimroth, C. Reichardt, T.Siepmann, F.Bohlmann, Ann. Chem., 661, 1(1963).

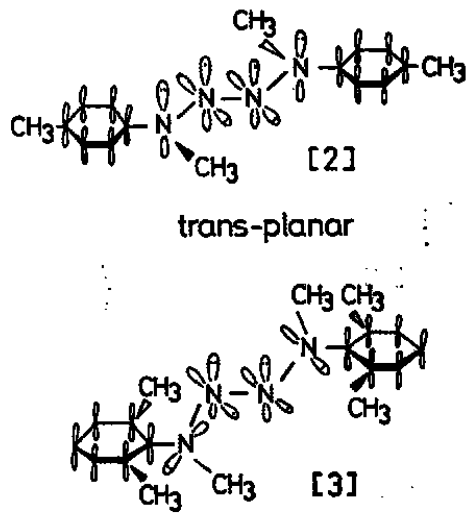

trans-orthogonal

\section{3 溶媒奻果}

[1]の $k_{\mathrm{d}}$ はメチル基の数と位監の变化にかかわらず,すべ ての 2-テトラゼンについて溶媒の極性バラメーター $E_{\mathrm{T}}$ 值 ${ }^{26)} の$

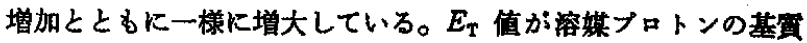
に対する付与能の目安であることから，溶媒ブロトンが [1]の $\mathrm{N}^{1}, \mathrm{~N}^{4}$ に付加しやすいほど分解恃促進される傾向にあるといえ る ${ }^{80)}$ 。一方，[1]の熱分解反㕯はいずれの溶媒においてる[1 e] $\gg[1 \mathrm{~d}]>[1 \mathrm{~b}]>[1 \mathrm{c}]>[1 \mathrm{a}] \gg[1 \mathrm{~g}]>[1 \mathrm{f}]$ の順に起こりゃ すい。〔1]の熱分解におよぼすメチル基の效果は各種活性化八 ラメーターにも反映している。 $\Delta H^{*}$ は $E_{\mathrm{T}}$ 值の増大とともに娍 少しており, 中性分子が逼移状態で函性の大きい構造を通って分 解することを意味している31382)。

そこで，分解におよぼす睓換基の相遧と溶媒の極性の圆係を明 らかにするために $\Delta H^{*}$ と $E_{\mathrm{T}}$ 値の関係を図1にプロットした。 $E_{\mathrm{T}}$ 値の変化による $\Delta H^{*}$ の変化の程度は図 1 の各直線の傾きか 5. $[1 \mathrm{e}]>[1 \mathrm{c}]>[1 \mathrm{~b}]>[1 \mathrm{a}]>[1 \mathrm{f}]>[1 \mathrm{~g}]$ であった。こ れから、のーィチル体の[1 e]は溶媒の䞚性の影繁を大きく受け

27) W.G.Bentrude, J.C.Martin, J.Am.Chem.Soc., 84, 1561(1962).

28) J.C.Martin, T.W.Koenig, ibid., 86, 1771(1964).

29) W.M.Tolles, D.W. Moore, W.E. Thun, ibid., 88, 3476(1966).

30) F. Effenberger, T. Fischer, Tetrahedron, 26, 3029 (1970).

31) L.M.Arnett, J.Am.Chem.Soc., 74, 2027 (1952).

32) D. G. Hendry, G. A. Russell, ibid., 86, 2368(1964). 


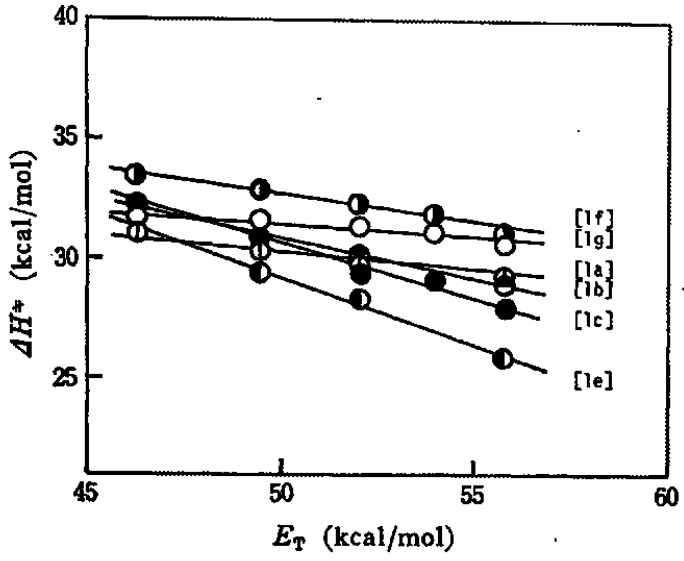

Fig. 1 Relationships between $\Delta H^{*}$ and $E_{\mathrm{T}}$-values

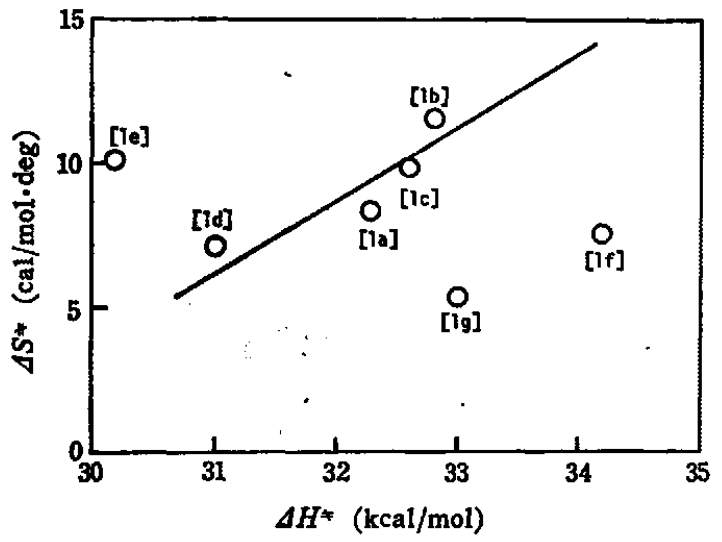

Fig. 2 Relationship between $\Delta H^{*}$ and $\Delta S^{*}$

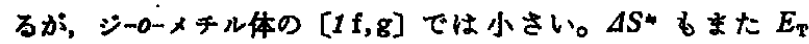
值の增加とともに娍少しており， $\Delta H^{*}$ と $\Delta S^{*}$ の変化はたがい

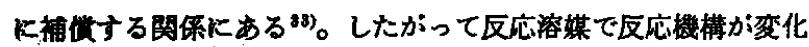
ナることはない。

一方, 蛋性効果のもっとも小さいフセトニトリル中では [1]の 贯喚基の相连に上る $\Delta H^{*}$ と $\Delta S^{*}$ の変化は四 2 に示すように興 味ある結果となった。。trans-planar 構造の [1 a, b, c, d ] では直 缐閉係が成立していると見られ，メチル基の位監が変わっても同 し譏構で分解することを示している。しかし, trans-orthogonal

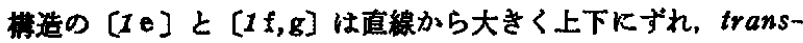
planar 体とは䔬なる機桡で分解すると思われる。 $[1 \mathrm{e}]$ の場合， 基底状態でオルト㕸メチルブロトンと $\mathrm{N}^{2}$ とが相互作用した構造 [8]になるが要移状照で相互作用が解消するので上にずれる。 一方， [1 g, f]は迶移状態で分解に有效なかなり制約された構造 〔7〕となるため下にずれたものと考えられる。

\section{4. 分解機模}

2.4.1[1 a, b, c, d ] の分解：基底状態で搆造 [3]の[1 a d】は $\mathrm{N}^{2}-\mathrm{N}^{2}$ 単結合がラジカル開裂するとを，まず生成する $N$ メチルフニリノラジカルの共鳴安定化エネルギーを得るために，

33) IJ.E.Leffer, E.Grundward, "Rate and Equilibria of Organic"Reactions", John Wiley \& Sons, Inc, New York (1963) Ch.9.
$\mathrm{N}^{1}-\mathrm{N}^{2}$ 単結合がフェニル環の面に严醇となった orthogonal 模造 [4]をとる》。このため，溶媒の $E_{\mathrm{T}}$ 值が增大すると $\mathrm{N}^{1}, \mathrm{~N}^{4}$ 位 の窒素へ溶媒ブロトンが付加して，カチオン性が增大し， $s p^{2}$ 混 成になり，orthogonal 構造をとりやすく，分解速度が增大する 之思われる。また，其役酸の $p K_{a}$ から，メチル基の尊入により 分解速度が増大するのは，ィチル基からベンゼン環を通して N $\sim \mathrm{N}^{4}$ 一電子が流九込み，窒素の非共有電子対相互間の反発が增 大するためであろう。以上の結果，および 2.3 項，さらに既報29) で述べたトリアゼニルラジカルを考虑すると，つぎの機構が考え られる。

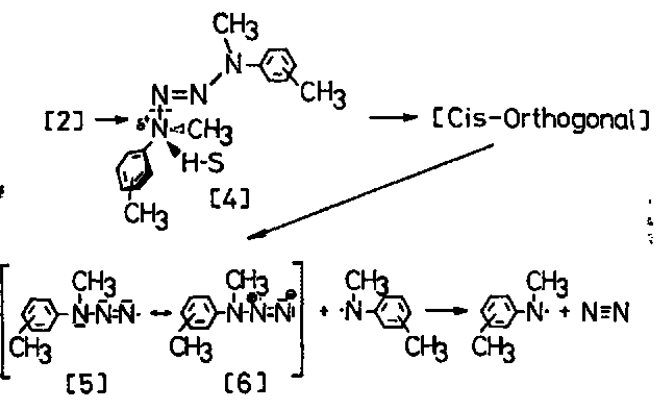

ここに，生じたトリアゼニルラジカル〔5]は極性構造 [6] の奇与で溶媒和によって安定化する。

2.4.2〔 [ $\mathrm{f}, \mathrm{g}]$ の分解: trans-orthogonal 檴造の[1f,g]忙 基底状態で， $\mathrm{N}^{1}-\mathrm{N}^{2}$ 単結合がフェニル環の面と直交しているもの の，きわめて分解速度は小さく， $\Delta H^{*} ゃ \Delta G^{*}$ は大きい。また， 溶媒の覀性の影繁は小さい。ところで，テトラインプロビル-2テトラゼンの光分解では trans-Cis の配座変化を経ると解裙 されている34)。また，cis-1,4-ジフタロイル-2-テトラセン (mp $\left.160^{\circ} \mathrm{C}\right)$ はトランス体 $\left(\mathrm{mp}>260^{\circ} \mathrm{C}\right)$ より分解温度が低く ${ }^{35)}$, さ らK, 3，3'-フゾシ(2-オキサゾリシノン) のシス体とトランス体

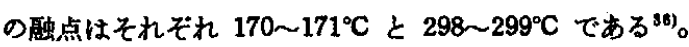

これらのことから、一般に芳香族 2-テトラゼンの分解か， trans -cis の構造变化を経て分解すると仮定すれば $[1 \mathrm{f}, \mathrm{g}]$ がきわめて分解しがたいことが㜔明できる。すなわち、二つのオ ルト位メチル基のために，[1 f,g]は $\mathrm{N}^{1}-\mathrm{N}^{2}$ および $\mathrm{N}^{3}-\mathrm{N}^{4}$ 単結 合がとるにフェニル愣の媔に垂直となった cis-orthogonal 構造 〔7〕にはきわめてなりにくいことが分子模型から明らかである。 しかし、〔1 a〜d]については，容易に cis-orthogonal 構造とな ることができる。

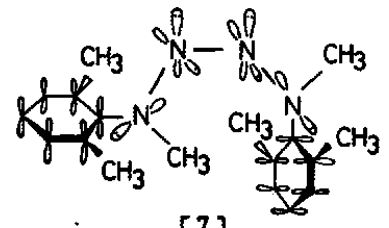

[7]

cis-orthogonal

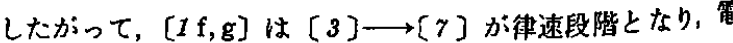

34) J.R. Roberts, K. U. Ingold, J.Am. Chem. Soc., 95, 3228 (1973).

35) D.W. Jones, Chem. Commun., 1970, 1084.

36) P.S. Forgione, G.S.Sprague, H.J.Troffkin, J. Am. Chem. Soc., 88, 1079(1966). 
子項より，立体项が垔要な因子となる。一方，〔1 a〜d]の分解に おいては〔2]—[4]が律速段階と考えられ，[4]はたたち に cis-orthogonal 棈造を絴て [5]とフンリノラジカルに分解 †る。

2.4.3[1 e]の分解: [1 e]は同じ orthogonal 槛造の $[1 \mathrm{f}$, g]と異なって, シス構造 [7]となるのに立体障害はない。ま た[1 e] の共役酸の $p K_{a}$ が大きいことから，オルト位メチル プロトンと $\mathrm{N}^{2}, \mathrm{~N}^{3}$ の非共有電子対との相互作用 [8]が考えられ

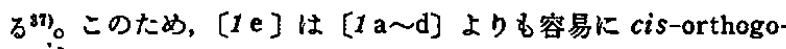
nal 榭造となり，分解しやすいと思われる。<smiles>Cc1ccccc1N(C)N(C)C</smiles>

[8]

同様のオルト効果が $[9 \mathrm{a}, \mathrm{b}]$ で見いだされている。

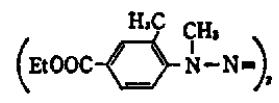

[9 a]

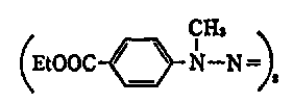

[9b]
この場合，[9 a ], [9 b]の分解速度此は $1: 0.003$ であっだ?。 以上のことから，[1]は trans—cis の構造变化を経て $\mathrm{N}^{1}$, N`の非共有笔子対間の反発によって分解することが明らかとな った。

\section{3 実 聒}

3.1 1,4-ジメチル-1,4-ジフェニル-2-テトラゼン [1 a ], 1,

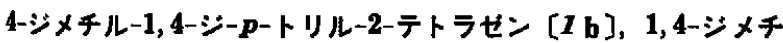

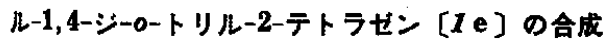

[1 a ] および [1 b]は Nelsen らの方法りにしたがって, 1メチル-1-フェニルヒドラジンおよび 1-メチル-1-pートリルヒド シシンををれぞれ酸化水銀 (II)で酸化して合成した。

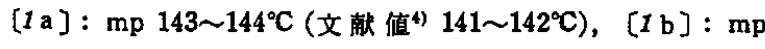
$149 \sim 150^{\circ} \mathrm{C}$ (文献値) $148 \sim 149^{\circ} \mathrm{C}$ )。

[1 e]は既報 ${ }^{28)}$ にしたがって合成した。 $\mathrm{mp} 78 \sim 79^{\circ} \mathrm{C}$ (分解)。

3.2 1,4-ジメチル-1, 4-ジ-m-トリル-2-テトラゼン $[\boldsymbol{l} \mathrm{c}]$ の 合成

$34 \mathrm{~g}(0.25 \mathrm{~mol})$ の 1-メチル-1-m-トリルとドラジンを $200 \mathrm{ml}$ の㜔嬠クロロホルムに加え，承冷下，かきまぜながら $35 \mathrm{~g}(0.5$ mol) の酸化水銀 (II)を 2 時間かかって少量ずつ加える。そのの ち室温にもどし，さらに 1 時間かきまぜる。反応終了後，办銀を 㭭し，母液は低温で溶媒を留去する。析出した $[1 \mathrm{c}]$ は四塩化 嵌素から再結晶した。 $\mathrm{mp} 117^{\circ} \mathrm{C}$ (分解)，収率 $33 \%$ 。

分析值 C $72.1 \%$ ， H 7.4\%，N $20.9 \%$

$\mathrm{C}_{16} \mathrm{H}_{20} \mathrm{~N}_{4}$ としての

計算值 C $71.61 \% ， \mathrm{H} 7.51 \% ， \mathrm{~N} \mathrm{20.88 \%}$

$\operatorname{NMR}\left(\mathrm{CDCl}_{3}\right)(\mathrm{ppm}): 2.33(\mathrm{~s}, 6 \mathrm{H}), 3.43(\mathrm{~s}, 6 \mathrm{H}), 6.58 \sim 7.40$ $(\mathrm{m}, 8 \mathrm{H})$

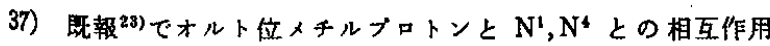

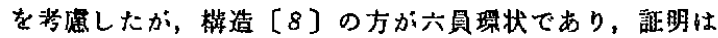
ないが桑当と思われる.

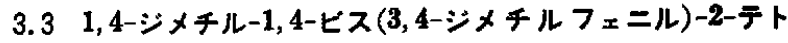
ラセン〔1 d]の合成

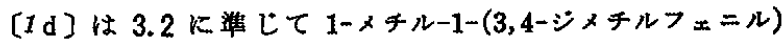
ヒドラシンを酸化水銀 (II) で酸化カップリングさせて得た。 mp $147 \sim 148^{\circ} \mathrm{C}$ (分解), 収率 $28.6 \%$ 。

分析值 C $73.4 \% ， \mathrm{H} 8.2 \%, \mathrm{~N} 18.3 \%$

$\mathrm{C}_{18} \mathrm{H}_{24} \mathrm{~N}_{4}$ としての

計算値 C $72.94 \%$, H $8.16 \%, N 18.90 \%$

$\mathrm{NMR}\left(\mathrm{CDCl}_{3}\right)(\mathrm{ppm}): 2.20(\mathrm{~s}, 6 \mathrm{H}), 2.23(\mathrm{~s}, 6 \mathrm{H}), 3.40(\mathrm{~s}, 6$ $\mathrm{H}), 6.98(\mathrm{~m}, 6 \mathrm{H})$

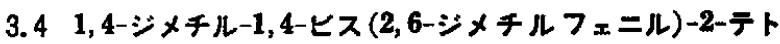
ラゼン〔l f ]

[1 f]は 3.2 に準じて 1-メチル-1-(2,6-ジメチルフェニル)飞 ドラシンを酸化水銀（II）で醊化カッブリングさせて得た。

$\mathrm{mp} 131 \sim 132^{\circ} \mathrm{C}$ (分解), 収率 $64.8 \%$ 。

分析值 C $72.9 \%, H 8.2 \%, N 18.8 \%$

$\mathrm{C}_{18} \mathrm{H}_{24} \mathrm{~N}_{4}$ としての

計算值 C $72.94 \%$ ，H $8.16 \% ， N 18.90 \%$

$\operatorname{NMR}\left(\mathrm{CDCl}_{\mathrm{s}}\right)(\mathrm{ppm}): 2.2(\mathrm{~s}, 12 \mathrm{H}), 3.15(\mathrm{~s}, 6 \mathrm{H}), 7(\mathrm{~s}, 6 \mathrm{H})$

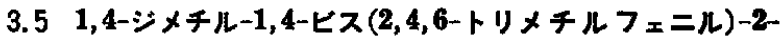
テトラゼン $[\boldsymbol{I g}]$ の合成

[1 g]は 1-メキル-1-(2,4,6-トリメチルフェニル)ヒドラジン を，3.2. K準じて酸化水銀(II)て酸化カッブリングさせて得た。 $\mathrm{mp} 167^{\circ} \mathrm{C}$ (分解)，収率 $52 \%$ 。

分析值 C 74.0\%, H $8.7 \%, \mathrm{~N} 17.3 \%$

$\mathrm{C}_{20} \mathrm{H}_{28} \mathrm{~N}_{4}$ としての

計算值 C 74.03\%, H $8.70 \%, \mathrm{~N} 17.27 \%$

$\operatorname{NMR}\left(\mathrm{CDCl}_{\mathrm{s}}\right)(\mathrm{ppm}): 2.15(\mathrm{~s}, 12 \mathrm{H}), \quad 2.22(\mathrm{~s}, 6 \mathrm{H}), \quad 3.13(\mathrm{~s}, 6$ $\mathrm{H}), 6.8(\mathrm{~s}, 4 \mathrm{H})$

\section{6 分解生成物の単離}

$3.6 .1[1 \mathrm{~b}]$ の熱分解: $3 \mathrm{~g}(0.01 \mathrm{~mol})$ の[1 b]を $200 \mathrm{ml}$

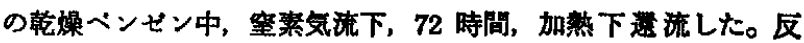
応終了後， $2 \mathrm{~N}$ 㙁酸で塩基性物筫を抽出する。抽出液は中和のの

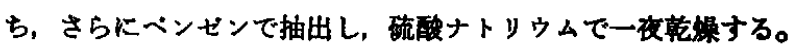
抽出液はベンぜンを留去したのち，残留物を真空蒸留して bp 83 $\sim 84^{\circ} \mathrm{C} / 8 \mathrm{mmHg}$ の無色の液体 $1.2 \mathrm{~g}$ を得た。IR, NMR から $N-$ メチルーp-トルイシンと同定した（文献値 ${ }^{88)} 206 \sim 207^{\circ} \mathrm{C}$ )。

$3.6 .2[1 \mathrm{e}]$ の䓡分解: $5 \mathrm{~g}(0.02 \mathrm{~mol})$ の [1 e]をヘンンセン

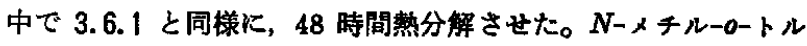
イシシン bp $73^{\circ} \mathrm{C} / 8 \mathrm{mmHg}$ (文献値 ${ }^{39)} 207 \sim 208^{\circ} \mathrm{C}$ ) が $0.8 \mathrm{~g}$ 得ら れた。なお，[1 a ] の熱分解では $N$-メチルアニリンのみが得ら れているい。

\section{7 溶 媒}

分解反応に用いたメタノール，エタノール，2-プロパノール， およびアセトニトリルは常法により精製したるのを用いた。

\section{8 分解速度の測定}

既知量 $\left(0.37 \sim 5.56 \times 10^{-5} \mathrm{~mol} / \mathrm{l}\right)$ の[1]を内径 $10 \mathrm{~mm}$, 長 さ $12 \mathrm{~cm}$ のガラス管に入れ、ドライフイスーメタノール浴で命や

38) Beilsteins Handbuchd. Org.Chem. Hw. Eg. II, 12, 902(1929).

39) ibid., 17, 784(1929). 


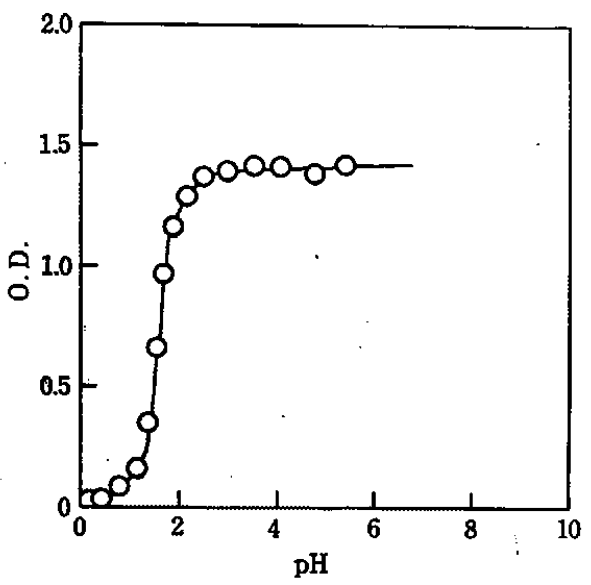

Fig. 3 Change in absorbance at $347 \mathrm{~nm}$ of $[1 \mathrm{a}]$ with $\mathrm{pH}$ in $20 \%(\mathrm{v} / \mathrm{v})$. dioxane-hydrochloric acid

し溶封する。封管は定温器に入れ，所定温度 $\left( \pm 0.02^{\circ} \mathrm{C}\right)$ でふり まぜた。所定時間㛙分解させたのち，内容物をUV 娜定に供し た。 UV スペクトルは島津製 Double Beam Spectrophotometer UV-200Sで得た。[1]の熱分解速度はそれぞれの $\lambda_{\max }$ にお。 ける吸収強度の減少を追跡して求めた。なお分解生成物の吸収は [1]の $\lambda_{\max }$ 付近にはない。〔1]の䈨度と吸取の変化は実験濃
度䈖围で Beer 则にしたがった。一次分解速度定数 $\left(k_{\mathrm{d}}\right)$ は次式 から算出した。

$$
k_{\mathrm{d}}=1 / t \ln \left(D_{0} / D_{t}\right)
$$

ここに， $D_{0}$ および $D_{l}$ はとれぞれ時間 0 および時間 $t$ のとき の光学密度である。

\section{9 活性化ハララメーター ${ }^{40)}$ の算出}

Arrhenius の活性化エネルギー $E_{\mathrm{a}}$ は $\log k_{\mathrm{d}}$ 対 1/T のブロ ットから推定した。活性化ェンタルピーは $\Delta H^{*}=E_{\mathrm{a}}+\boldsymbol{R} T$ か ら求めた。活性化ェントロピーは次式から求めた。

$$
k_{\mathrm{d}}=(k T / h) \cdot \exp \left(-\Delta H^{*} / \boldsymbol{R} T\right) \cdot \exp \left(\Delta S^{*} / \boldsymbol{R}\right)
$$

また $\Delta G^{*}$ は $\Delta G^{*}=\Delta H^{*}-T \Delta S^{*}$ を用いて算出しだ。

3.10 $\boldsymbol{p} \boldsymbol{K}_{a}$ の測定

〔1]の共役酸の $p K_{a}$ は，敇々の $\mathrm{pH}$ 值に調整した $20 \%(\mathrm{v} /$ v) ジオキサン-塩酸泥合溶媒中，〔1]の $\lambda_{\max }$ に和ける吸収強 度の変化から得た滴定型曲線(1)にも基ついて求めた。[1 a $]$ の場 合を図 3 に示す。

40) S.Glasstone, K.J. Laidler, H.Eyring, "The Theory of Rate Processes", McGraw-Hill Inc., New York (1941) Ch. 1.

41) F.T.King, R.C.Hirt, Appl.Spectrosc., 7, 164(1953).

Thermal Decomposition of 1,4-Dimethyl-1,4-bis(methylsubstituted phenyl)-2-tetrazenes

Tetsuo OdA*, Toshihisa Maeshima* and Kazuo Sugryama**

* Department of Applied Chemistry, Faculty of Science and Engineering, Kinki University; Kowakae, Higashi-Osaka-shi 577 Japan

** Department of Applied Chemistry, Faculty of Engineering, Kinki University; Hiro-machi, Kure-shi 737-01 Japan

1, 4-Dimethyl-1, 4-bis (methyl-substituted phenyl)-2-tetrazenes [1] can be classified into two conformational groups according to spectral data : trans-planar types $[1 \mathrm{a}, \mathrm{b}, \mathrm{c}, \mathrm{d}]$ having the methyl groups at 3 or/and 4 positions on phenyl groups, and trans-orthogonal types $[1 \mathrm{e}, \mathrm{f}, \mathrm{g}]$ with the methyl groups at 2 or/and 6 positions on phenyl groups. The rates of thermal decomposition of [1] have been determined in various protic solvents by means of UV spectroscopy. Rate constants $\left(k_{\mathrm{d}}\right)$ which increase with the polarity of the solvents are in the order $[1 \mathrm{e}] \gg[1 \mathrm{~d}]>[1 \mathrm{~b}]>[1 \mathrm{c}]>[1 \mathrm{a}] \gg[1 \mathrm{~g}]>[1 \mathrm{f}]$ in all solvents. A linear relation is found for a plot of $\Delta H^{*}$ against the solvent polarity parameter $\left(E_{\mathrm{q}}\right)$. A compensating change is found in $\Delta H^{*}$ and $\Delta S^{*}$ for each [ 1$]$ in various solvents, showing that a single mechanism is operative for the thermal decomposition of $[1]$ in various solvents. On the other hand, the reaction mode differs somewhat between trans-planar and trans-orthogonal types of [1]. The decomposition of [ 1$]$ appears to proceed via conformational change of trans-planar $\stackrel{a}{\longrightarrow}$ trans-orthogonal $\stackrel{\mathrm{b}}{\longrightarrow}$ cis-orthogonal. Steps $\mathrm{a}$ and $\mathrm{b}$ are rate-determining step for the decomposition of $[1 \mathrm{a}, \mathrm{b}, \mathrm{c}, \mathrm{d}]$ and $[1 \mathrm{e}, \mathrm{f}, \mathrm{g}]$, respectively. 